Article

\title{
Evaluation of EZStrobe Simulation System as a Tool in Productivity Analysis-A Case Study: Precast Concrete Hollow-Core Slab Installation
}

\author{
Wisoot Jiradamkerng \\ Civil Engineering Department, College of Engineering, Rangsit University, 52/347 Muang Ake, \\ Phaholyothin Road, Lakhok, Pathumthani 12000, Thailand \\ E-mail: wisoot_j@yahoo.com
}

\begin{abstract}
This research's objective was to evaluate the EZStrobe simulation system as a tool in productivity analysis by selecting precast concrete hollow-core slab installation work as a case study. The study started from determination of work elements of precast concrete slab installation work, after that the time data for each work element were collected from construction site to meet $95 \%$ confidence interval and 5\% limit of error. The Multiple-Activity-Chart then was created, using average time required for each work element, to derive for cycle time of installation work. The alternated tool, EZStrobe simulation system, then was introduced to determine for cycle time by creating a model with stochastic time data. The results, in term of basic cycle time and idle time percentages, from simulation had been compared with deterministic method, MultipleActivity-Chart model, which validated that EZStrobe simulation system could well represent the construction process. After that, more complicated model was created to see the effectiveness of the system by simulating more realistic site conditions e.g. limited space for hollow-core slab truck in site, number of precast concrete slab per truck. The required results; basic cycle time ( $\mathrm{min}$ ), standard cycle time (min), productivity (pieces/day and square meter/day), and unit cost (Baht/piece); were also formulated in this new model. These outcomes were very useful for construction planning, scheduling and unit cost estimation. Furthermore, the EZStrobe simulation system could give the insight understanding of construction processes for work study and improvement. After all evaluation, the researcher found that this non-commercial EZStrobe simulation system was very worth using for productivity analysis and also the user-friendly Microsoft Visio(C) interfaces were truly enhanced the system performances, especially in creating the models.
\end{abstract}

Keywords: EZStrobe, construction process simulation, productivity, multiple-activitychart.

ENGINEERING JOURNAL Volume 17 Issue 2

Received 29 September 2012

Accepted 25 November 2012

Published 1 April 2013

Online at http://www.engj.org/

DOI:10.4186/ej.2013.17.2.75 


\section{Introduction}

In a construction project, there were many parties involved such as owner, designer, construction management, and contractor. The nature of construction business was very competitive and all parties had to improve themselves all the time to find a place to stand, especially the contractor.

The contractors had to win in bidding to get the project. So, most of them try to keep their competitiveness in the industry, and the productivity of their construction team was one of crucial factors to their cost. There were many questions came up to contractor that how well was their productivity and how much was the real unit cost of the construction works. Knowing their actual productivity will be the basis for unit cost analysis and, in the same time, for productivity improvement for better, easier construction method, and of course lower cost.

\section{Objectives}

This research's objective was to evaluate the EZStrobe simulation system as a tool in productivity analysis by selecting precast concrete hollow-core slab installation work as a case study. The outcomes from EZStrobe will be compared to the conventional deterministic method, Multiple-Activity-Chart, in various aspects. After that, more complicated model was created to see the effectiveness of the system by simulating more realistic site conditions to reflect actual productivity and unit cost.

\section{Method and Results}

The construction productivity standard in Thailand was still not well established. Lacking of the data makes professional engineer turns to data from overseas [1] even though there exists some errors according to variations of working condition.

Some contractors in Thailand had their own collected productivity from in-house construction crews, while researchers in construction industry applied more theoretical methods to determine it [2]. The productivity analysis could be done by determination of cycle time of the construction operation by two different approaches [3] firstly, deterministic, which the calculations could be done in algebraic method; secondly, stochastic approach which taking into account the probability distribution of time duration of each work element in the studied construction operation.

\subsection{Determination of Cycle Time by Deterministic Method}

For this study, we select Installation works of precast concrete hollow-core slab sizing of $200 \mathrm{~mm} \times 900 \mathrm{~mm}$ $\times 8.00 \mathrm{~m}$ as a case study. The data were collected from 6-storey building project in Pathumthani province of Thailand. The installation works were broken in to 5 work elements as shown in Fig. 1 for time study purposes.

The 36 samples of time duration of each work element were collected in order to meet $95 \%$ confidence interval and within 5\% limit of error, which was validated with Eq. (1), assuming that the distribution of time duration follow normal distribution. The average time duration of each work element in Table 1 were used in creating the Man-Machine Chart [4] or Multiple-Activity-Chart (MAC) as shown in Fig. 2.

$$
N=\left[\frac{\frac{k}{s} \times \sqrt{n^{\prime} \Sigma x_{i}^{2}-\left(\Sigma x_{i}\right)^{2}}}{\Sigma x_{i}}\right]^{2}
$$

Provided that $N$ : Required number of samples (must equal or less than $n$ ), $n^{\prime}$ : Actual number of sample, $k$ : the standard score from Normal curve for $95 \%$ confidence (1.96), s: Limit of error (0.05). 


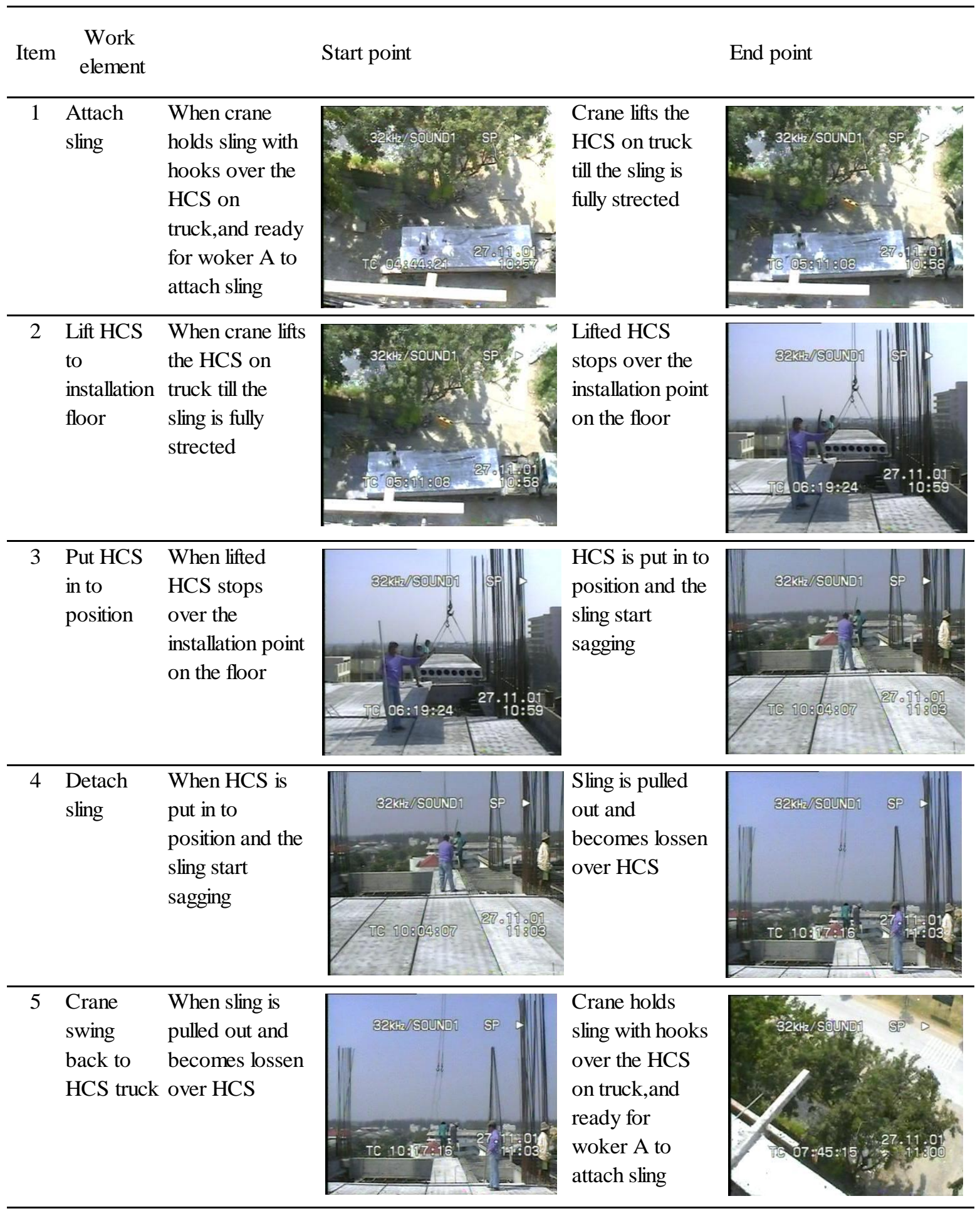

Remark: $\quad$ HCS $=$ Precast concrete hollow-core slab

Fig. 1. Work elements of hollow-core slab installation works with start and end point for time study.

From Fig. 2, the cycle time of precast concrete slab installation work was then marked in the MAC, which was equal to 195 seconds, when the process was in steady state. 
Table 1. Average cycle time of each work element of hollow-core slab installation works.

\begin{tabular}{|c|c|c|c|c|c|}
\hline \multirow[t]{2}{*}{ Item } & \multicolumn{3}{|c|}{ Work element } & \multirow{2}{*}{$\begin{array}{l}\text { Average } \\
\text { cycle time } \\
\text { (minute) }\end{array}$} & \multirow{2}{*}{$\begin{array}{l}\text { Average } \\
\text { cycle time } \\
\text { (second) }\end{array}$} \\
\hline & Name & Start point & End point & & \\
\hline 1 & Attach sling & $\begin{array}{l}\text { When crane holds sling } \\
\text { with hooks over the HCS } \\
\text { on truck, and ready for } \\
\text { worker A to attach sling }\end{array}$ & $\begin{array}{c}\text { Crane lifts the HCS on } \\
\text { truck till the sling is fully } \\
\text { stretched }\end{array}$ & 0.43 & 26 \\
\hline 2 & $\begin{array}{l}\text { Lift HCS to } \\
\text { installation } \\
\text { floor }\end{array}$ & $\begin{array}{l}\text { When crane lifts the HCS } \\
\text { on truck till the sling is } \\
\text { fully stretched }\end{array}$ & $\begin{array}{l}\text { Lifted HCS stops over } \\
\text { the installation point on } \\
\text { the floor }\end{array}$ & 1.39 & 84 \\
\hline 3 & $\begin{array}{l}\text { Put HCS in to } \\
\text { position }\end{array}$ & $\begin{array}{l}\text { When lifted HCS stops } \\
\text { over the installation point } \\
\text { on the floor }\end{array}$ & $\begin{array}{l}\text { HCS is put in to position } \\
\text { and the sling start } \\
\text { sagging }\end{array}$ & 0.39 & 23 \\
\hline 4 & Detach sling & $\begin{array}{l}\text { When HCS is put in to } \\
\text { position and the sling start } \\
\text { sagging }\end{array}$ & $\begin{array}{c}\text { Sling is pulled out and } \\
\text { becomes loosen over } \\
\text { HCS }\end{array}$ & 0.25 & 15 \\
\hline 5 & $\begin{array}{l}\text { Crane swing } \\
\text { back to HCS } \\
\text { truck }\end{array}$ & $\begin{array}{l}\text { When sling is pulled out } \\
\text { and becomes loosen over } \\
\text { HCS }\end{array}$ & $\begin{array}{l}\text { Crane holds sling with } \\
\text { hooks over the HCS on } \\
\text { truck, and ready for } \\
\text { worker A to attach sling }\end{array}$ & 0.79 & 47 \\
\hline
\end{tabular}

Remark: HCS = Precast concrete hollow-core slab

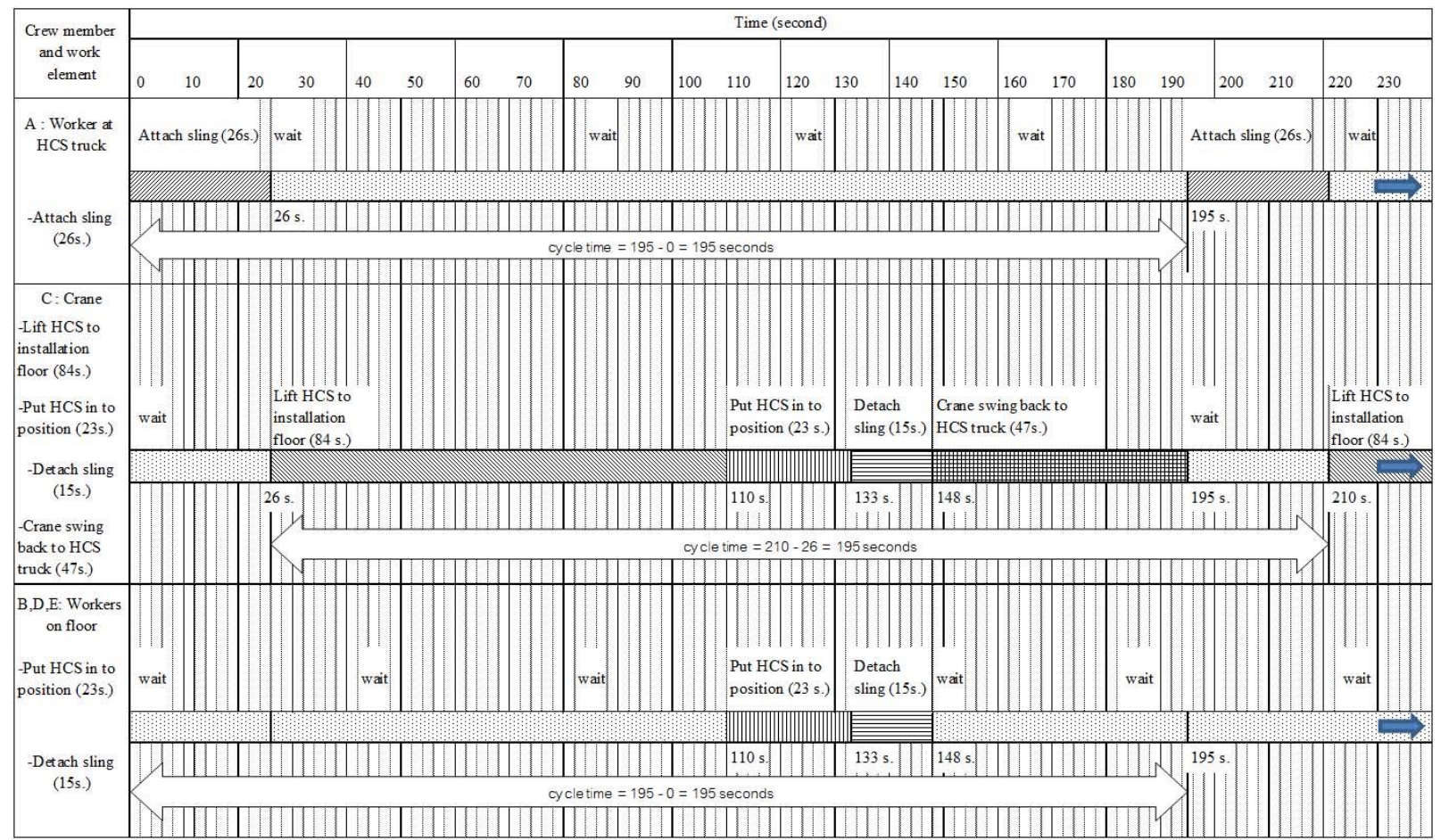

Fig. 2. Multiple-Activity-Chart showing cycle time of hollow-core slab installation. 


\subsection{Determination of Cycle Time by Stochastic Method}

The above cycle time from MAC model simply used average durations of each work element in preparation, which did not take into account the variation of time durations. This shortcoming had been solved by designing of simulation system with stochastic approach. Many simulation systems were developed for construction work e.g. Visual SimNet [5], CYCLONE [6], and more advanced one as EZStrobe [7] which was designed to use simple interfaces as Microsoft Visio (C Microsoft Inc.) in creating a simulation model and transition to more advance tools STROBOSCOPE [8].

Table 2. The main components of EZStrobe.

Elements Function Parameter Description

Queue Holds idle resource until used
Combi $\quad \begin{aligned} & \text { Constrained activity that can start } \\ & \text { whenever required resources are available }\end{aligned}$

Normal

Fork

Link

Connects different activities and queues

An activity that is not constrained and that can start whenever a preceding activity is complete

A probabilistic element to randomly select the path to follow
1) Que name

2) Number of Resources

1) Combi name

2) Probability distribution density function

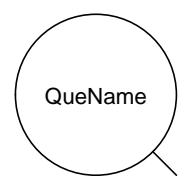

1) Normal name

2) Probability distribution density function

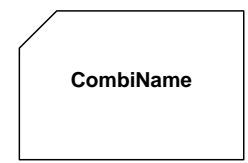

$\mathrm{N} / \mathrm{A}$

1) Condition necessary for the successor activity to start

2) Number of resources to be consumed

Break up a complex model into several Fusion Queue pages, is assumed to be the same as the ordinary queue the are named after
$\mathrm{N} / \mathrm{A}$

QueName 
Table 3. Probability distribution functions of each work element.

\begin{tabular}{lll}
\hline Item & \multicolumn{1}{c}{ Name } & Proability distribution function \\
\hline 1 & Attach sling & $\operatorname{TRIA}(0.3,0.463,0.58)$ \\
2 & Lift HCS to installation floor & $\operatorname{NORM}(1.39,0.0973)$ \\
3 & Put HCS in to position & $\operatorname{NORM}(0.389,0.0778)$ \\
4 & Detach sling & $\operatorname{TRIA}(0.19,0.261,0.31)$ \\
5 & Crane swing back to HCS truck & $\operatorname{TRIA}(0.42,0.845,1.09)$ \\
\hline
\end{tabular}

The main components of EZStrobe were the Queue, Combi, Normal, Fork, and Link elements. These components had their own function, parameter, and description as shown in Table 2. The researcher used these elements to draw Activity Cycle Diagrams (ACDs) for representing any construction operation or process for simulation.

The Combi and Normal component in EZStrobe ACDs contained probability distribution functions of time durations. So, the time data of each activity had to be tested with statistic software package for the best fitted probability distribution function as shown in Table 3.

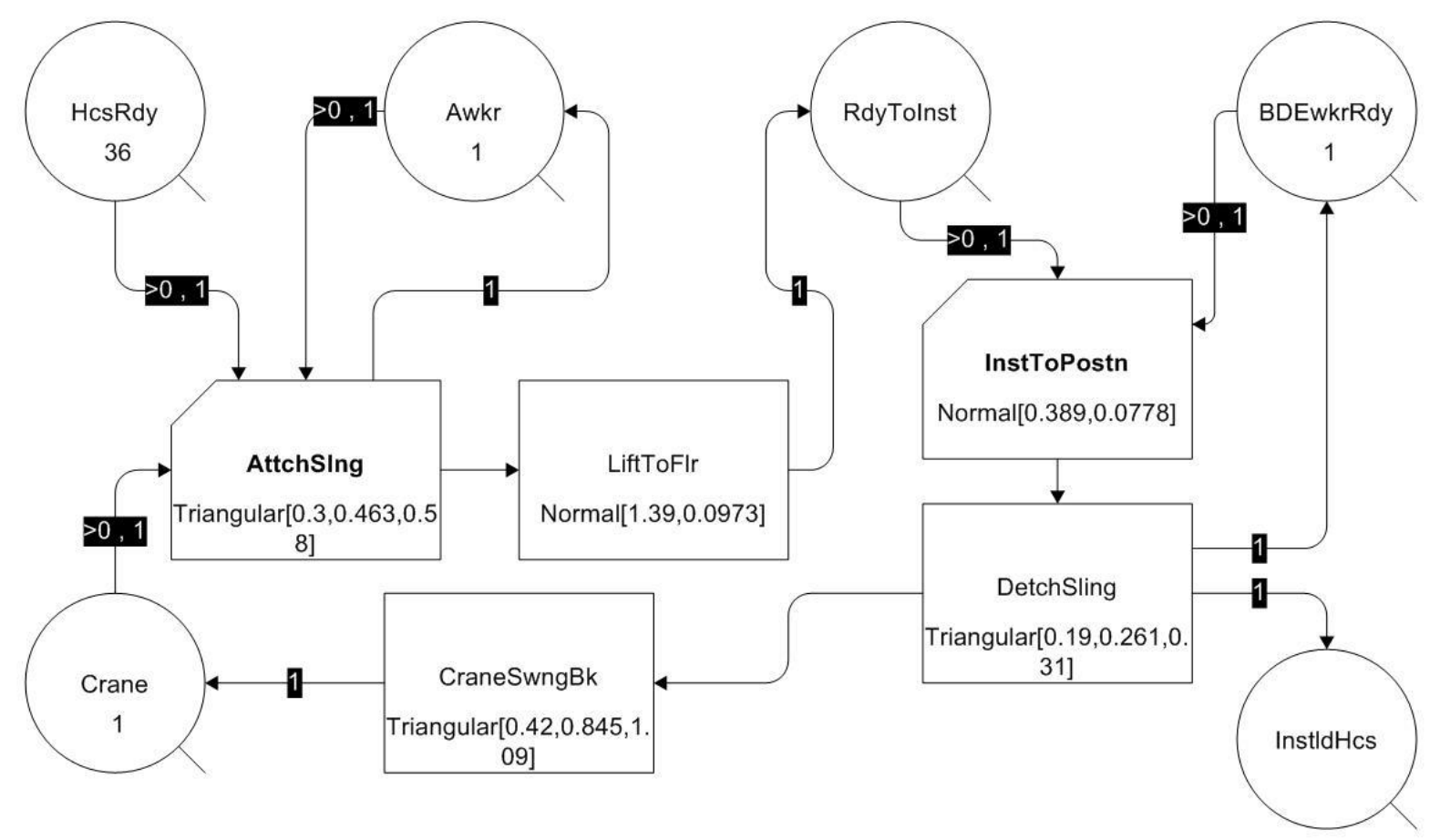

Fig. 3. EZStrobe ACDs showing installation works of 36 pieces of hollow-core slab.

The data in Table 3 had been input to EZStrobe as shown in Fig. 3, assigning that there were 36 pieces of hollow-core slab to be installed according to the number data collected. The results from simulation model showed that average cycle time was 3.26 minutes comparing to MAC's result of 3.25 minutes (195 seconds); the percentages of idle time of each crew member were nearly the same as shown in Table 4, but for the crane, there was no idle time shown from EZStrobe which was different from MAC model. 
Table 4. Comparison of results from MAC model and EZStrobe model.

\begin{tabular}{llccr}
\hline Item & \multicolumn{1}{c}{ Results } & unit & MAC model & EZStrobe \\
\hline 1 & Cycle time for installation per piece of HCS & minute & 3.25 & 3.26 \\
2 & Percentage of idle time & & & \\
2.1 & A : Worker at HCS truck & $\%$ & $86.67 \%$ & $86.00 \%$ \\
2.2 & B,D,E: Workers on floor & $\%$ & $80.51 \%$ & $81.00 \%$ \\
2.3 & C : Crane & $\%$ & $7.69 \%$ & $0.00 \%$ \\
\hline
\end{tabular}

This was because of EZStrobe did not consider the waiting time of crane for worker A to attach sling as idle time, since the crane was not in the QueName "Crane" throughout the operation. The outcomes above indicated that EZStrobe simulation model could well represent the processes of construction work and gave us more insight understanding of them.

\subsection{Application of EZStrobe Simulation System for Productivity and Unit Cost Analysis}

The simulation model that could represent real life construction conditions was the ideal objective of the researcher. In this case study, the researcher found out that the parking area for hollow-core slab truck was limited to only one truck at a time, and other arrived hollow-core slab trucks had to wait outside nearby the site. In this situation, after hollow-core slab in the first truck had been installed, the crew had to wait for the empty truck to move out (1.80 minutes) and the new hollow-core slab truck to get in place (2.20 minutes).

The hollow-core slab truck could carry 10 pieces of hollow-core slab per trip, and total 11 trips were required for this case study floor area. So, the researcher decided to add extra ACDs for truck entering and moving out of the parking area; the total number of truck was 11, and each of them carried 10 pieces of hollow-core slab, which could be drawn as shown in Fig. 4.

The required results from running simulation could be reported by adding boxes of "Parameter" and "Result" as shown in the top right and bottom of Fig. 4. In the "Parameter" boxes, the number of truck was represented by variable "nHcs'Trk", cost per hour of crane was 800 Baht and of all workers (A,B,D,E) was 200 Baht, so we could change these numbers to see what-if scenarios. For the "Result" box, we could enter calculation formulas for the results required e.g. Basic cycle time of hollow-core slab installation (minutes), Standard cycle time (minutes), Productivity (pieces/day), Productivity (square meter/day), and Unit Cost (Baht/piece).

As the basic cycle time of a construction operation would be the basis for productivity and unit cost estimation. In real life, the basic cycle time could not be used directly to analyze for productivity, since the workers should have some relaxation and contingency allowances [9]. In this case, estimated allowances were shown in Table 5 according to working conditions. Then, the productivity and unit cost could be determined for further usages. 


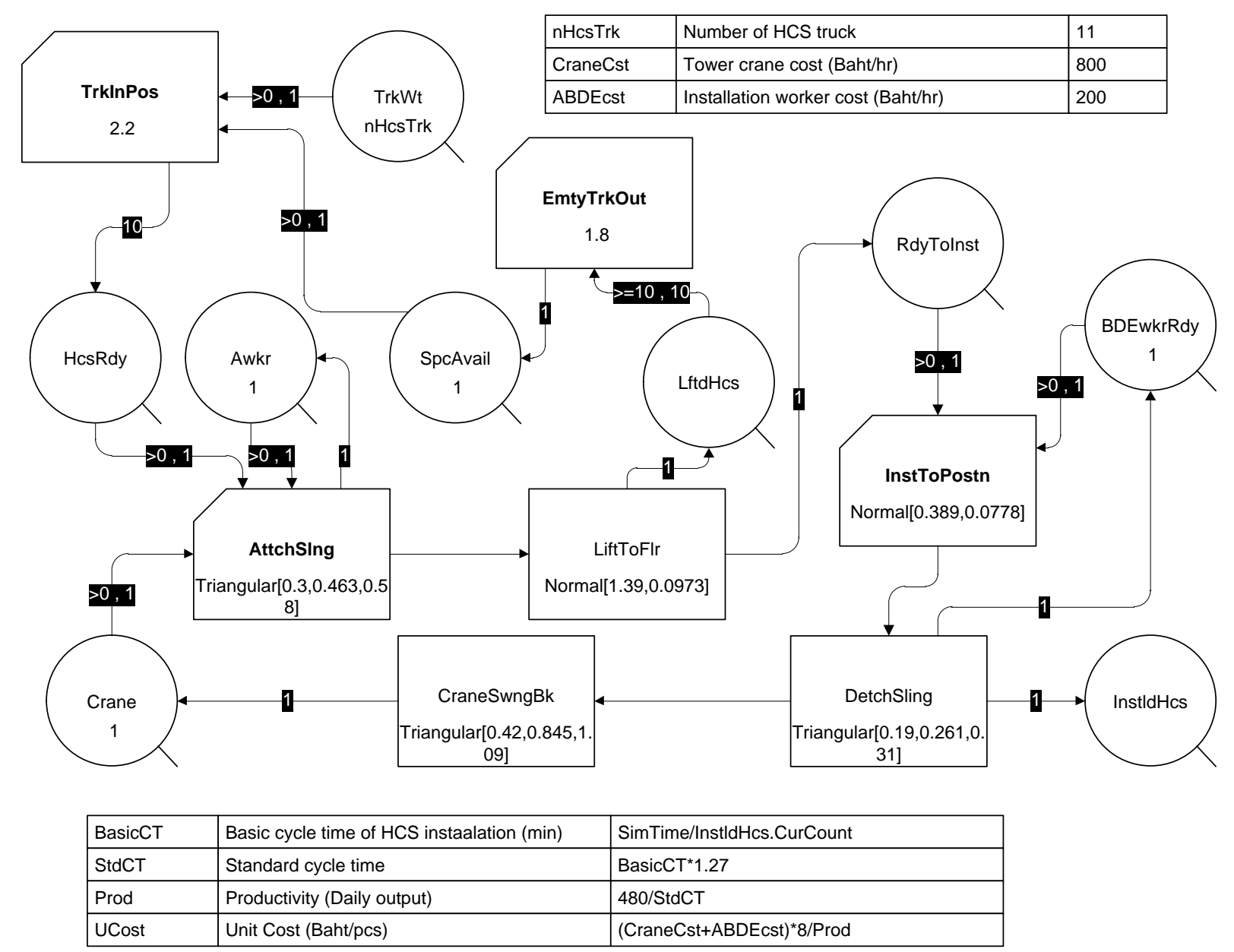

Fig. 4. EZStrobe model for hollow-core slab installation with more realistic site conditions.

Table 5. Estimated relaxation and contingency allowances from site conditions [9].

\begin{tabular}{llc}
\hline Item & \multicolumn{1}{c}{ Relaxation allowances } & $\%$ \\
\hline 1 & Fixed allowance & $8.0 \%$ \\
2 & Effort and dexterity & $6.0 \%$ \\
3 & Posture & $0.0 \%$ \\
4 & Fatigues & $6.0 \%$ \\
5 & Visual & $0.0 \%$ \\
6 & Noise & $2.0 \%$ \\
7 & Concentration & $0.0 \%$ \\
8 & Working condition & $0.0 \%$ \\
\hline & Total & $22.0 \%$ \\
\hline & Add for contingency allowances & $5.0 \%$ \\
\hline \multicolumn{2}{c}{ Total allowances } & $27.0 \%$ \\
\hline
\end{tabular}

The analysis results shown in Fig. 5 explained that the effect of limited truck parking area makes the basic cycle time in this case longer than the earlier model. The standard cycle time was derived by adding $27 \%$ allowances to basic cycle time, and productivity was calculated based on 8-hour working day. These productivity figures would be very useful for planning and scheduling works, and also reflect the unit cost, 
which made the project management team realize that his construction crew was making profit or loss to the company.

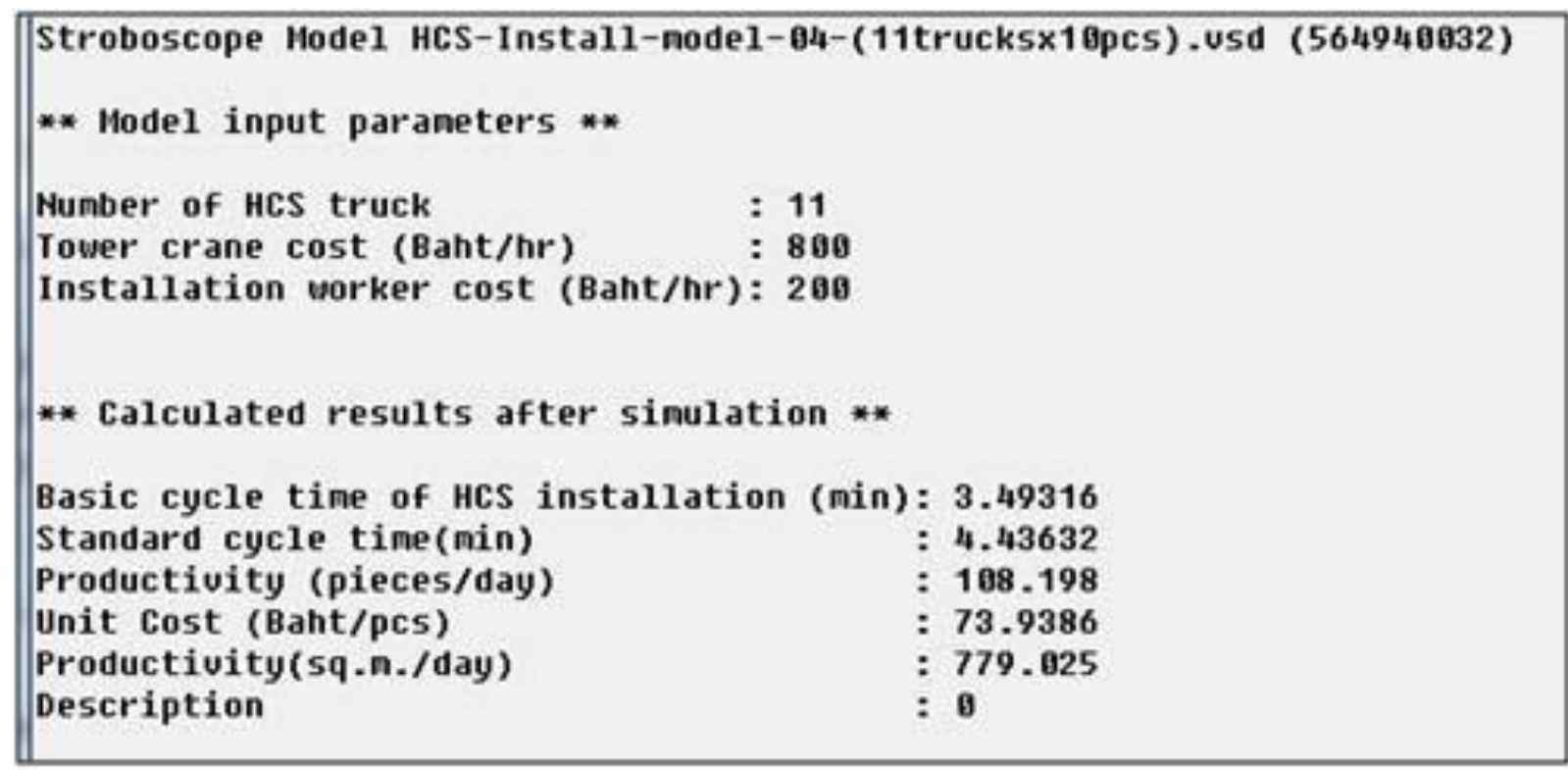

Fig. 5. Results from EZStrobe simulation system for 11 trucks case.

\section{Conclusion}

This research's objective was to evaluate the EZStrobe simulation system as a tool in productivity analysis by selecting precast concrete hollow-core slab installation work as a case study. The results, in term of basic cycle time and idle time percentages, from simulation had been compared with conventional deterministic method, Multiple-Activity-Chart model, which validate that EZStrobe model could well represent the construction process. After that, the researcher had reconstructed an extended EZStrobe simulation model to reflect site conditions e.g. the limited space for precast concrete slab truck that only one truck at a time could enter to site, the number of precast concrete slab carried per truck was 10 pieces.

The required results were also formulated in this new model, which showed that basic cycle time for installation work of $200 \mathrm{~mm} \times 900 \mathrm{~mm} \times 8.00 \mathrm{~m}$ precast concrete slab was 3.49 minutes, standard cycle time was 4.44 minutes, productivity of the given construction crew was 108.20 pieces/day or 779.02 square meter/day, and unit cost was $73.94 \mathrm{Baht} /$ piece. These outcomes were very useful for construction planning and scheduling works, cost estimation, and also in cost control process. Furthermore, the EZStrobe simulation system could give the insight understanding of construction processes for work study and improvement.

After all evaluation, the researcher found that this non-commercial EZStrobe simulation system was very worth using for productivity analysis and also the user-friendly Microsoft Visio@ interfaces were truly enhanced the system performances, especially in creating the models. Lastly, the researcher would like to express his gratitude to the authors of this highly efficient tool, EZStrobe simulation system, for their contributions to academicians and research works in related fields. 


\section{References}

[1] R. S. Means Company, Inc., Productivity Standard, 3rd ed. Kingston: s.n., 1994.

[2] W. Jiradamkerng, S. Thongmai, and N. Pongpatanasuegsa, "Studying and preparing of basic time for piling works by synthetic equations," Engineering Journal, vol. 15, no. 4, pp. 1-10, 2011.

[3] S. R. Miller and A. G. Dorée, "Improving logistics in the asphalt paving process: What can we learn from planner's logic?," in Proc. of 24th Annual ARCOM Conference, Cardiff, UK: Association of Researchers in Construction Management, 2008, pp. 381-390.

[4] P. Olomolaiye, A. Jayawardane, and F. Harris, Construction Productivity Management. Singapore: Addison Wesley Longman, 1998.

[5] W. Garbe, Visual SimNet User's Manual. s.l.: Unpublished, 1996.

[6] D. W. Halpin and L. S. Riggs, Planning and Analysis of Construction Operations. New York: John Wiley \& Sons, 1992.

[7] J. C. Martinez, "EZStrobe-general-purpose simulation system based on activity cycle diagrams," in Proc. Winter Simulation Conference, vol. 2. Arlington, VA: s.n., 2001. pp. 1556-1564.

[8] J. C. Martinez, "Stroboscope," Ph.D. dissertation, University of Michigan, Ann Arbor, MI, 1996.

[9] F. C. Harris and R. McCaffer, Modern Construction Management, 4th ed. Oxford: Blackwell, 1995. 